\title{
The role of Panama Canal in global shipping
}

Mariner Wang

\author{
Graduate School of Management, Ritsumeikan Asia Pacific University, \\ Beppu, Japan
}

\begin{abstract}
Purpose - The purpose of this study is to find out the future development of the Panama Canal after opening of the new waterway (third set of locks project), in terms of the change of cargo throughput, further deployment of fleets by the shipping companies and competition for the canal.

Design/methodology/approach - The research of this paper is based on an empiric study by collecting the relevant data from annual report of the Panama Canal Authority, publications related to the same field. Graphs pertaining to toll revenue also are made based on statistical data provided by the Panama Canal Authority.

Findings - The findings show that the opening of the new waterway of the Panama Canal generates more toll revenue for Panama government by allowing mega-vessels to transit, expediting further economic development of the country largely from behind. At the same time, shipping operators also can enjoy earning more revenue by deploying New Panamax vessels transiting the Canal.
\end{abstract}

Originality/value - Ingenuity in tabling the users of the Panama Canal by incorporating the logo marks of the shipping companies/implication is drawn through empirical analysis to provide the shipping companies and ports authorities concerned with more understanding toward the very significance of the new waterway expansion of the Panama Canal.

Keywords Intermodal transportation, All-water service, Double stack train, New-Panamax vessels, Post Panamax vessels, Toll revenue

Paper type Research paper

\section{Introduction}

Canals are manmade channels (waterways). They are of great significance to global logistics because they change geography by removing barriers to international trade (Wood et al., 1995). However, over the past three decades, the economic significance of canals has lessened, particularly the Panama Canal.

This is partly because of the emergence of international intermodal transportation, e.g. the introduction of Double-Stack Train (DST) service in North America since 1984, and partly because of shortcomings of canal transportation, such as seasonal use when located in cold weather climates (Sampson et al., 1990).

For several decades, as a major conduit (water passage) for international maritime trade, the Panama Canal (77 kilometers), which is an artificial waterway, has been playing a crucial role as the ship canal that cuts across the Isthmus of Panama in Central America connecting the Atlantic, via the Caribbean Sea, to the Pacific Ocean.

Because of the width constraint of the original locks (only 33.5 meters), inevitably many large size container vessels heading for east coast of North America from Asia could not

(c) Pacific Star Group Education Foundation 
MABR

2,3

248

traverse the Panama Canal, and instead, by using DST at the port of Portland, Oakland or Long Beach in the west coast.

With an aim to provide carriers with easier and more access, a third set and wider lane of water locks (Figure 1) was constructed between September 2007 and May 2016. From June 26, 2016, the new locks allow the transit of larger, Post-Panamax ships, capable of handling more cargoes. So far as the distance is concerned, a vessel sailing from New York to San Francisco via the canal travels $8,370 \mathrm{~km}$, which is well under half of the $20,900-\mathrm{km}$ route around Cape Horn.

Initial construction of the Panama Canal in 1904 was completed in 1914, making it no longer necessary for vessels to sail the lengthy and hazardous Cape Horn route. The canal shortcut made it possible for vessels to travel between the Atlantic and Pacific Oceans in half the time previously required.

The Panama Canal, connecting the Atlantic and Pacific Oceans, is perhaps the most crucial piece of infrastructure supporting the free flow of international trade and goods in the western hemisphere. Vessels passing through the lakes and locks travel approximately

Figure 1.

Diagram of the Panama Canal

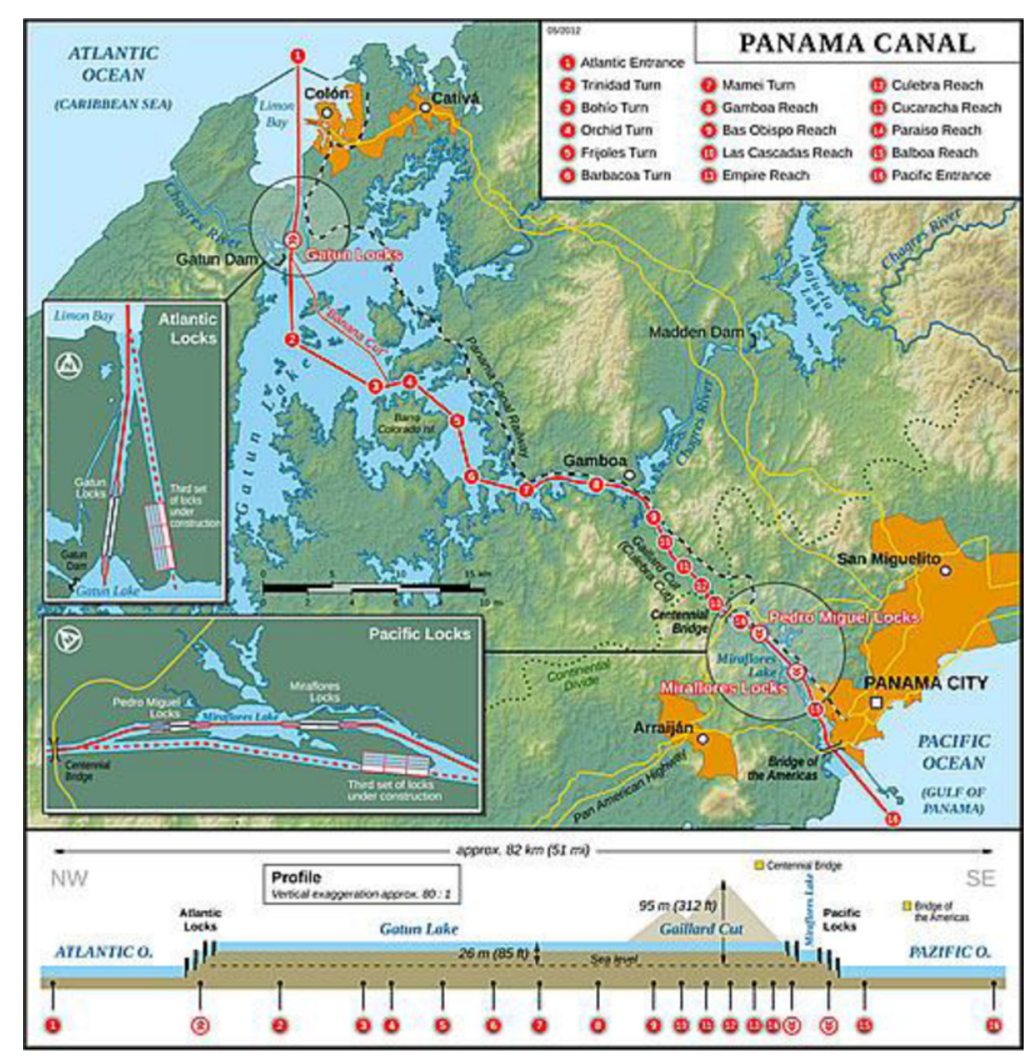

Sources: Image: Thomas Römer, Wikipedia Panama Canal Map: www.nationsonline.org/oneworld/map/google_map_Panama_Canal.htm 
$77 \mathrm{~km}$ between the entrances of the Atlantic and Pacific Oceans, eliminating the lengthy and often precarious route around Cape Horn in South Africa.

The new waterway passage across the Panama Canal is one of the supreme human achievements of all time, which can absolutely compete with the Port and Airport Development Strategy (PADS) project in Hong Kong and the Eurotunnel, which bridges between Britain and France. The new waterway expansion of the Panama Canal is one of the hardest works ever won by human effort and ingenuity. The American Society of Civil Engineers has named the Panama Canal one of the seven wonders of the modern world.

Following a host of delays and uncertainties pertaining to the completion of the much anticipated expansion project, the expanded waterway (the third set of locks project) began commercial operation on June 26, 2016.

Today, it only takes six to eight hours for vessels to pass through the Panama Canal compared with almost one day before the expansion simply because vessels could not pass side-by-side, and Panamax-sized vessels were prohibited from using the canal at night.

\section{Handover of the Panama Canal sovereignty from the USA to Panama}

In 1904, the USA took over the operations of the Panama Canal and the Canal Zone surrounding it since its beginnings, and it was not until September 7, 1977 that TorrijosCarter Treaties provided for the transition of control to Panama.

The treaties highly guaranteed that Panama would gain control of the Panama Canal after 1999, ending the sovereignty of the canal that the USA had exercised since 1903. Sooner, after the handover of the sovereignty of the Panama Canal from the USA to the Government of Panama, Autoridad del Canal de Panama (ACP), namely, Panama Canal Authority, the entity of the Government of Panama then began to assume command of the long expected international trade waterway.

Because of its importance and uniqueness in many fields, the ACP is financially autonomous, having ss

The ACP, in coordination with Panama government entities designated by law, is also highly responsible for the management, maintenance, utilization and conservation of the water resources of the canal watershed, including lakes and their tributary streams.

The Panama Canal was under the management of joint US-Panamanian administration from 1979 to 1999. Before the handover, the Panama Government held an international bid to negotiate a 25-year contract for the operation of the container shipping ports located at the Canal's both Atlantic and Pacific outlets. Surprisingly, the contract was not affiliated with the ACP but was won by Hutchison Whampoa Limited (HWL), one of the world-renowned Hong Kong-based container terminal operators.

HWL, a Fortune Global 500 company, was an investment holding company based in Hong Kong. It was one of the largest companies listed on the Hong Kong Stock Exchange.

HWL was an international corporation with a diverse array of holdings, which included the world's leading container terminal - Hong Kong International Terminals (HIT) - and telecommunication operations in 14 countries that were run under the three brand names. Its businesses also included retailing, property development and infrastructure. It was 49.97 per cent owned by the Cheung Kong Group[1].

On June 3, 2015, HWL merged with the Cheung Kong Group as part of a major reorganization of the group's businesses. The combined business was renamed CK Hutchison Holdings Limited. 
MABR

2,3

\section{The role of Panama Canal locks}

The Panama Canal locks are a lock system that lifts a ship up 26 meters to the main elevation of the Panama Canal and down again. The original canal had six steps (three up and three down) for a ship's passage[2]. The total length of the lock structures, including the approach walls, is over $3 \mathrm{~km}$. The locks, when opened in 1914, were one of the greatest engineering works ever to be undertaken.

The Panama Canal comprises 17 artificial lakes including several improved artificial channels and 12 locks. The locks system is a two-step flight at Miraflores Locks (Pacific side), and a single flight at Pedro Miguel lock (Pacific side), lifting vessels from the Pacific Ocean up to Gatun Lake (Atlantic side); then a triple flight at Gatun lock lowers them to the Atlantic Ocean[3].

The lift at Miraflores Locks actually varies due to the extreme tides on the Pacific side, between 13 meters at extreme high tide and 20 meters at extreme low tide. However, in comparison, tidal differences on the Atlantic side are very small.

Of particular note is that all of the above-mentioned three sets of locks are paired, that is, there are two parallel flights of locks at each of the three lock sites. The design successfully allows vessels to traverse in opposite directions simultaneously. However, large vessels just cannot cross safely at speed in the Culebra Cut. Therefore, in practice, vessels transit in one direction for a time, then in the other, using both lanes of the locks in one direction at a time.

The size of the locks along the passage of the Panama Canal determines the maximum size of vessels being able to traverse the canal. Because of the extreme importance of the canal in terms of international trade and shipping, many vessels are built, then, to the maximum size allowed with an aim to carry more cargoes.

These types of vessels are known as "Panamax vessels" with a beam of around 32.3 meters, length approaching 294.13 meters and carrying capacities of about up to 4,400 TEU/ 65,000-80,000 deadweight tonnage (DWT). However, its actual cargo is restricted to about 52,500 DWT because of draft restriction in the canal.

\section{The Panama Canal users}

The ACP and the Panama Government have been positively striving to maintain the waterway as the pivotal route of choice for international trade. In its ongoing efforts to satiate the demands of the maritime industry, the ACP has been aggressively keeping in touch with major shipping companies by dispatching delegation or launching port sales to get a better understanding of the market it serves and make pertinent decisions pertaining to the canal's plans for the future.

Part of the ACP's corporate mission is to foster lasting relationships with major shipping operators running the gamut from container vessels to LNG vessels, LPG tankers and cape size vessels, etc. which have been using the Panama Canal, understanding and satiating with their needs, adding value to their business and offering high quality services. For this, keeping constant contact with shipping companies is vitally important to the future business of the canal.

As of September 31, 2015, the shipping companies that are using the Panama Canal come from 18 countries, including the world's top three shipping conglomerates - Maersk (Denmark), MSC (Switzerland) and CMA CGM (France) (Figure 2).

\section{Oceangoing vessels transiting the Panama Canal}

According to statistical data provided by the ACP, there are around 40 per cent of the USbound cargoes going through either Los Angeles or Long Beach, while 60 per cent of the 


\begin{tabular}{|c|c|c|c|c|c|}
\hline \multicolumn{2}{|c|}{ Shipping Line } & \multirow{2}{*}{$\begin{array}{c}\text { Nationality } \\
\text { Singapore }\end{array}$} & \multicolumn{2}{|r|}{ Shipping Line } & \multirow{2}{*}{$\begin{array}{l}\text { Nationality } \\
\text { Denmark }\end{array}$} \\
\hline $\overrightarrow{\mathrm{AP}}$ & APL & & MAERSK & Maersk Line & \\
\hline CMACGM & CMA CGM & France & $\frac{\sqrt{00}}{\text { बल }}$ & MSC & Swiss \\
\hline$=\Phi_{x=}$ & cosco & China & MOL & MOL & Japan \\
\hline$\triangle C S A V$ & CSAV & Chile & ENXK. & NYK & Japan \\
\hline & Evergreen & Taiwan & Beratade & $\begin{array}{l}\text { Seatrade Reefer } \\
\text { Chartering NV }\end{array}$ & Netherland \\
\hline Hamuerites & Hamburg-Sud & Germany & stxpinotean & STX Pan Ocean & Korea \\
\hline & Hanjin & Korea & wiv & Wallenius Wilhelmsen & Norway \\
\hline 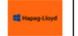 & Hapag-Lloyd & Germany & & Yang Ming & Taiwan \\
\hline GKLINE. & $\mathrm{K}$ Line & Japan & (2in) & ZIM & Israel \\
\hline
\end{tabular}

\section{Role of \\ Panama Canal in global shipping}

Source: Tabled by the author based on relevant data

Figure 2.

Users of the Panama

Canal (as of September 2015)

traffics transiting the Panama Canal beginning or ending its journey at a US port. The competition between ports at US east and west coasts continues.

The Panama Canal has seen the rise of annual cargo traffic from approximate 1,000 vessels transit (ocean going commercial traffic) since opened in 1914 to 12,386 oceangoing vessels transit in 2015 and down to 11,688 oceangoing vessels transit in 2016 (Figure 3).

The drop in fiscal year 2016 was attributed to the many challenges for the Panama Canal, among them:

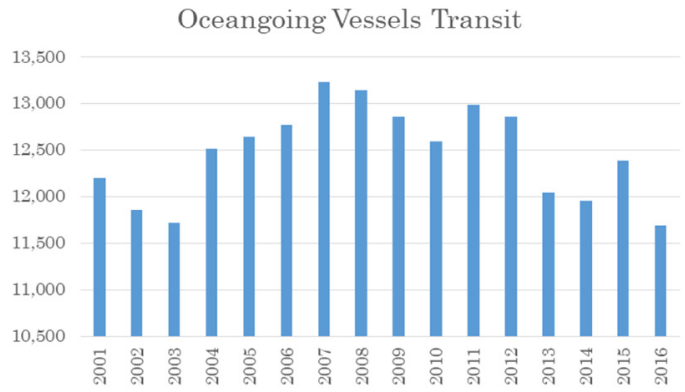

Note: Fiscal year: 1 October-30 September

Source: Made by the author based on the statistical data of Anmual Report 2001-2016, Canal De Panama and other relevant data

Figure 3. Annual Panama

Canal transit (commercial traffic) 


\section{MABR}

2,3

\section{2}

The dropping in transit is seen to largely attribute to the use of DST from the west coast of North America by the major ocean carriers deploying the Post-Panamax vessels, particularly the super large container vessel, which just cannot traverse the Panama Canal due to the width constraint of the locks, on the Asia/North American trade route.

The PC/UMS (Panama Canal/universal measurement system) tonnage at the end of fiscal year 2014 was 326.8 million, an increase of 1.9 per cent from fiscal year 2013. The total cargo through the Panama Canal registered 222.4 million long tons, an 8.6 per cent increase over the previous year.

Before the new waterway expansion, only 3 per cent of the world's trade transported through the canal annually, 68 per cent of that originating or ending up in the USA. Apart from containers, the principal commodities are grain, chemicals, petroleum products, coal, coke, minerals, metals and phosphates (Table I).

The main trade routes are from the US East Coast to both Asia and the west coast of South America and from Europe to the USA West Coast, Canada, Asia and the west coast of South America.

According to the statistical data from Canal De Panama Annual Report (2014), apart from the US major users (and their percentage of world trade), are Ecuador (import 41.1 per cent and export 21.8 per cent); Peru (import 35.5 per cent and export 17.0 per cent); Chile (import 32.3 per cent and export 21.6 per cent); Columbia (import 20.2 per cent and export 9.6 per cent); Mexico (import 10.4 per cent and export 5.3 per cent); Venezuela (import 10.3 per cent and export 1.0 per cent); China (import 1.6 per cent and export 3.3 per cent); Japan (import 1.7 per cent and export 3.2 per cent).

The importance of the new expansion project (the third set locks project) has been highly illustrated by the continuing problem that vessels have been facing in getting swift access to the Panama Canal as demand for its services has been ever increasing. Vessels waiting to transit the canal have become a regular feature.

The projects have increased the canal's capacity to 330 million tons: the new expansion will nearly double that to 600 million tons. However, the tolls will be increased around doubling by 2025 to cover the expansion expenses

Table I.

The principal commodities transiting the Panama Canal

\begin{tabular}{lrrrrrrr}
\hline Commodity & 2010 & 2011 & 2012 & 2013 & 2014 & 2015 & 2016 \\
\hline Grain & $14.7 \%$ & $15.2 \%$ & $14.4 \%$ & $13.9 \%$ & N.A. & N.A. & N.A. \\
Chemicals & $6.6 \%$ & $6.2 \%$ & $5.8 \%$ & $6.0 \%$ & N.A. & N.A. & N.A. \\
Containerized cargo & $3.6 \%$ & $3.6 \%$ & $3.6 \%$ & $3.7 \%$ & N.A. & N.A. & N.A. \\
Coal and coke & $1.1 \%$ & $1.5 \%$ & $1.3 \%$ & $1.7 \%$ & N.A. & N.A. & N.A. \\
Minerals and metals & $1.8 \%$ & $1.7 \%$ & $1.7 \%$ & $1.6 \%$ & N.A. & N.A. & N.A. \\
Oil and oil derivatives & $0.5 \%$ & $0.6 \%$ & $0.6 \%$ & $0.5 \%$ & N.A. & N.A. & N.A.
\end{tabular}

Notes: \% of total metric tons; Statistical data for cargo type percentage on the Annual Report 2014-2016 of ACP are not available

Source: ACP with information from HIS, July 2014 
In essence, the new expansion project will increase the locks potential by more than 90 per cent.

\section{Why third set of locks project[5]?}

As demand has been on the rise, the Panama Canal is positioned to be a significant feature of world shipping for the near future. However, changes in shipping patterns, particularly the increasing numbers of Post-Panamax vessels, will necessitate changes to the canal should she to retain a significant market share.

In 2011, 37 per cent of the world's container vessels were too large to traverse the Panama Canal, and hence, a failure to expand the waterway will result in a substantial loss of revenue gained from the shipping operators.

The maximum sustainable capacity of the canal before expansion, given some relatively minor improvement work, is estimated at between 330 and 340 million PC/UMS tons per year, and this capacity had reached in 2012.

According to statistical data, about 50 per cent of the transiting vessels were already using the full width of the locks. Undoubtedly, the expansion of third set of locks project is necessary. The proposal to support the ACP's $\$ 5.28 \mathrm{bn}$ new waterway expansion project was finally approved in a national referendum by an overwhelming 76.8 per cent on October 22 , 2006.

The project refers to the expansion of the Panama Canal. Completed in June 2016, it is for two new flights of locks to be built parallel to, and operated in addition to, the old locks, one east of the existing Gatun locks (Atlantic side) and one southwest of the Miraflores Locks (Pacific side), each with three chambers.

The new locks will be supported by new approach channels, including a $6.2-\mathrm{km}$ channel at Miraflores (Pacific side) from the locks to the Gaillard Cut or Culebra Cut, skirting Miraflores Lake. Each of these channels will be 218-meter wide, which can provide PostPanamax vessels with ample space to navigate the channels in one direction at a time.

Each flight will ascend from sea level directly to the level of Gatun Lake; the existing two-stage ascent at Miraflores and Pedro Miguel locks will not be replicated.

The new lock chambers are featured with sliding gates, doubled for safety and are 427-meter long, 55-meter wide and 18.3-meter deep. This allows the transit of vessels with a beam of from 32.2 meters up to 49 meters, an overall length of up to 366 meters and a draft of up to 15 meters, equivalent to a container ship carrying around 12,000 TEUs.

Meanwhile, the Gaillard Cut and the channel through Gatun Lake has been widened to at least 280 meters on the straight portions and at least 366 meters on the bends. The maximum level of Gatun Lake has been raised from 26.7 to 27.1 meters. In addition, deepening the Culeba Cut has also been incorporated. This enables larger vessels than ever before to pass this waterway.

Each flights of locks are accompanied by nine water reutilization basins (three per lock chamber), each basin being about 70-meter wide, 430-meter long and 5.50-meter deep. These gravity-fed basins allow 60 per cent of the water used in each transit to be reused; the new locks consequently use 7 per cent less water per transit than each of the existing lock lanes.

The deepening of Gatun Lake and the raising of its maximum water level provide capacity for significantly more water storage. These measures are intended to allow the expanded canal to operate without constructing new reservoirs.

The new expansion project reached its 8 per cent completion in September 2014, constituting a paradigm shift for world trading, particularly for Panama and the main users of the canal, including China, the USA, Chile and Ecuador. 
MABR

2,3

254

Vessels take two hours to transit the new locks, meaning a maximum of 12 transits per day, on top of the 40-plus transits already being done, though some of these may transfer to the new locks. The expanded waterway is predicted to have a maximum sustainable cargo traffic capacity of about 600 million PC/UMS tons per year.

The project is designed to allow for an anticipated growth in cargo traffic from 280 million PC/UMS tons in 2005 to nearly 510 million PC/UMS tons in 2025.

\section{Dredging of the Panama Canal and neighboring ports[6]}

With an aim to allow deeper-draught New-Panamax cargo vessels (49-meter wide, 366-meter in length overall and with a 15.2-meter (tropical freshwater) draught) to easily traverse the Panama Canal, the ACP had a heavy workload in dredging the waterway to be deeper.

At the same time, with 40 per cent of the US-bound cargoes going through either Los Angeles or Long Beach, most ports on the US east and Gulf of Mexico coast were being dredged in preparation for the New-Panamax vessels and are upgrading their equipment before the completion of the expansion project.

For example, Port of Houston Authority was positively preparing for an uptick in cargo traffic to its port expected to come soon after the completion of the new waterway. The $\$ 3 \mathrm{bn}$ in upgrades to the port's berths, cranes and other facilities are in the hopes that the canal expansion project will be a financial blessing to Texas and Houston, in particular.

The dredging of the Panama Canal includes excavating 15 million $\mathrm{m}^{3}$ in Caribbean Sea/ Atlantic entrance, 20 million $\mathrm{m}^{3}$ in Gatun Lake; 9 million $\mathrm{m}^{3}$ in the Gaillard Cut; 9.11 million $\mathrm{m}^{3}$ from the Pacific entrance; and other dredging work for terminal development and expansion.

Each of these individual projects presents its own challenges, but the most challenging area is the Gaillard Cut. The scope of project includes dredging to 17.5 meters from 14.6 meters and widening from the present minimum of 192 meters to a new minimum of 218 meters in the straights and 286 meters in the curves.

In 2009, the ACP released a request for proposals to dredge the canal's Atlantic entrance deepening the channel to 15.5 meters, involving the removal of 15 million $\mathrm{m}^{3}$ of material. Meanwhile, Dredging International (DI) NV - one of the world's renowned dredging companies of the Dredging, Environmental \& Marine Engineering (DEME) Group, has started work at the other end, where it is already deepening the Pacific entrance to a minimum of 15.1 meters mean low water spring (MLWS) from its existing 14.2 meters. DI is also responsible for widening this area from 192 to 225 meters.

DI has split the project into eight sections, each of which will be dredged over two phases: first, the removal of relatively soft material; second, the removal of rock. DI has also won a contract to dredge the new Panama Pacific International Terminal that Singaporean PSA International, one of the world's famous container terminal operators, is building on the old Rodman naval base.

Another project being planned is the deepening of the Atlantic anchorage, possibly involving another 12.6 million $\mathrm{m}^{3}$.

\section{The competition of the Panama Canal}

Despite having enjoyed a privileged geographic advantage for many years, the Panama Canal is increasingly facing competition from other quarters. As the canal tolls are on the rise, some critics have suggested that the Suez Canal, the waterway for Asia/European trade route, may become a viable alternative for cargo en route Asia to the US East Coast.

From the viewpoint of port management and operation, cost, consistency and capacity are the crucially important determinants as the shipping gateway through which Asian 
imports enter the USA. The initial competition for the US business has not been west coast versus east coast[7], but rather with the Suez Canal route from Asia. In fact, two Suez services have shifted to the Panama route since the opening of the new waterway of the Panama Canal[8].

In addition to being a shorter distance to the east coast of North America from major loading hubs in Asia, the Panama Canal route is considered more efficient with fewer intermediate stops. In concrete, it takes 10 days longer for an exported container ship to travel from a major Chinese port, such as Shanghai Port or Dalian Port, to the US East Coast via the Panama Canal, than it does if it were to go through the more expensive option of a west coast port, such as Port of Los Angeles or Long Beach, and then via intermodal shipment by using DST to the east coast.

However, for those low- and mid-value shipments, where the transit time is not critical/ big concern, the cheaper all-water route (the trade route from Asia to the US East and Gulf Coasts via the Panama Canal) via the Panama Canal is the ideal option for the shippers. The Panama Canal serves more than 145 of the world's trade routes and the majority of canal traffic comes from the all-water route.

The increasing rate of melting of ice in the Arctic Ocean has led to speculation that the Northwest Passage or Arctic Bridge may become viable for commercial shipping at some point in the future. This route would save $9,300 \mathrm{~km}$ on the route from Asia to Europe as compared with the Panama Canal, possibly leading to a diversion of some traffic to that route[9].

However, such a route is beset by unresolved territorial issues and would still hold significant problems due to ice.

\section{Toll revenue and new toll structure of the Panama Canal[10]}

The toll revenue of the Panama Canal obtaining from the shipping companies has been a major revenue, which supports the economic growth of the republic of Panama largely from behind. As can be seen from Figure 4, the toll revenue of the Panama Canal has been ever increasing annually since 1998. In 2015, the amount was up to 1.99 billion PAB, a 3.7 folds increase over 1998. This is greatly attributed to the increased traffic (cargo) growth in the last 17 years, generating the high performance of the toll revenue[11].

However the toll revenue collected from the Panama Canal dropped to $1.93 \mathrm{PAB}$ billion in 2016 a 3.2 per cent drop compared with the preceding year. The declining revenue was

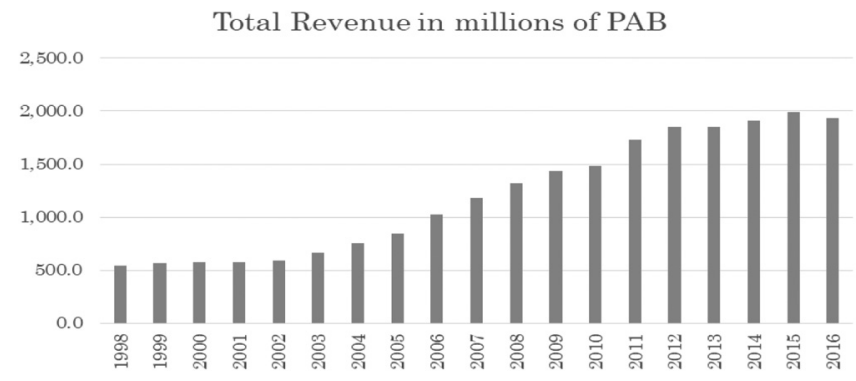

Note: Fiscal year: 1 October-30 September

Source: Graphed by the author based on the statistical data of Annual Report 1998-2016, Canal De Panama and other relevant data

Figure 4 . Annual toll revenue of the Panama Canal 
MABR

2,3

attributed to many challenges besetting the Panama Canal, such as the delay in the opening date of the new Neo-Panamax locks, the decrease in utilization levels due to market conditions, specifically in the United States with low import cargo volumes and high inventory levels in businesses. In addition, draught restrictions as a result of El Niño weather phenomenon during the months from April until June are seen as a big handicap which prevents vessels from transiting at their full capacity.

In preparation for the opening of the third lane of the Panama Canal, a new toll structure was approved in April 2015 by the Cabinet Council. This followed more than a year of informal consultations with the industry stakeholders, an open call for comments and a public hearing, with interested parties given an opportunity to provide feedback.

Effective on April 1, 2016, a more complicated toll system was introduced. Rate adjustments apply to both the existing canal and the new lane, when the new locks are set to become operational. The new toll structure establishes a basis for calculating prices based on different units of measurement for the different segments, that is, having the NewPanamax locks at a higher rate in some cases, liquefied natural gas transport (LNG vessels) as a new separate category and other changes. The new toll system carefully designed by the ACP is based on vessel type, size (length) and the type of cargo[12].

In concrete, small (less than 125 feet) vessels up to 583 PC/UMS net tons when carrying passengers or cargo, up to $735 \mathrm{PC} / \mathrm{UMS}$ net tons when in ballast or up to 1,048 fully loaded displacement tons, are assessed minimum tolls based upon their length overall.

As for container vessels (Table II), the toll is assessed on the vessel's capacity expressed in TEUs. The toll went from US\$74.00/TEU to US\$60.00/TEU capacity plus US\$30.00/TEU for a potential US\$90/TEU when the vessel is full. The toll is calculated differently for passenger ships and for container ships carrying no cargo (in ballast). As of April 1, 2016, the ballast rate is US\$60.00/TEU, down from US\$65.60/TEU[13].

As for bulk vessels, the toll is US\$5.25/ton for the first 10,000 tons, US\$5.14/ton for the next 10,000 tons and US\$5.06/ton, thereafter.

\section{The status of Panama Canal in international shipping}

The Panama Canal, bridging the Atlantic Ocean with the Pacific Ocean, has been playing a pivotal role in international shipping since its opening in August 1914. However, over the past three decades, the economic significance of the Panama Canal has lessened.

It is partly because of the emergence of intermodal transportation, e.g. introduction of DST service in North America since 1984, and partly because of the shortcomings of the canal transportation, such as navigating in cold weather climates and the constraint of vessel size because of the constraint of the locks width of the Panama Canal.

The new waterway expansion project is seen to be a driving force for the related sectors linking the canal traffic. It is expected to transform the prospects of Panama and will largely enhance the economy scale of the country as it allows the transit of mega-vessels (with beams of up to 49 and 15.2 meters in draft) through the new locks[14].

The expanded canal, being able to handle much large tonnage than before, implies opportunities arise for shipping operators to cascade vessels up to 14,000 TEUs capacity on services. It greatly provides carriers with more options, notably on Asia to South America and Asia to US East Coast routes. The two services can see larger vessels deployed to replace smaller tonnage currently used on the services.

Taking Denmark's Maersk line, for example, it had made more 400 transits through the Panama Canal in 2016, an increase from 313 in 2015 and 268 in 2014. The toll fee for the passages increased to more than US $\$ 100 \mathrm{~m}$ in 2016, from US\$80m and US\$62m in 2015 and 2014, respectively. 


\begin{tabular}{|c|c|c|c|c|}
\hline Locks & TEU Range & $\begin{array}{c}\text { Tariff for TTA } \\
\text { maximum capacity }\end{array}$ & $\begin{array}{l}\text { Tariff for loaded } \\
\text { containers onboard } \\
\text { (TEU) }\end{array}$ & $\begin{array}{r}\text { Panama Canal } \\
\text { in global }\end{array}$ \\
\hline \multirow{4}{*}{ Panamax 1} & $<1,000$ & $\$ 60$ & $\$ 30$ & \\
\hline & $\geqq 1,000<2,000$ & $\$ 60$ & $\$ 30$ & \\
\hline & $\geqq 2,000<3,500$ & $\$ 60$ & $\$ 30$ & \\
\hline & $\geqq 3,500 \leqq 5,100$ & $\$ 60$ & $\$ 30$ & 257 \\
\hline \multirow[t]{8}{*}{ Panamax 2} & $<6,000$ & $\$ 60$ & $\$ 40$ & \\
\hline & $\geqq 6,000<7,000$ & $\$ 50$ & $\$ 40$ & \\
\hline & $\geqq 7,000<8,000$ & $\$ 50$ & $\$ 40$ & \\
\hline & $\geqq 8,000<9,000$ & $\$ 50$ & $\$ 40$ & \\
\hline & $\geqq 9,000<10,000$ & $\$ 50$ & $\$ 35$ & \\
\hline & $\geqq 10,000<11,000$ & $\$ 50$ & $\$ 35$ & \\
\hline & $\geqq 11,000<12,000$ & $\$ 50$ & $\$ 35$ & \\
\hline & $\geqq 12,000$ & $\$ 50$ & $\$ 35$ & \\
\hline \multicolumn{3}{|c|}{ TEU tolls for non-container vessels that carry containers on deck } & $\$ 90$ & Table II. \\
\hline \multicolumn{4}{|c|}{$\begin{array}{l}\text { Notes: Panamax locks - for vessels with length of up to } 294 \mathrm{~m} \text { ( } 965 \mathrm{ft} \text { ), beam of up to } 32.31 \mathrm{~m} \text { (106 ft), draft } \\
\text { of up to } 12.04 \mathrm{~m}(39.5 \mathrm{ft}) \text {; Neo-Panamax locks - for vessels with length up to } 366 \mathrm{~m}(1,200 \mathrm{ft}) \text {; and/or beam } \\
\text { up to } 49 \mathrm{~m}(160 \mathrm{ft}) \text { and/or draft up to } 15.24 \mathrm{~m}(50 \mathrm{ft}) \text {; TTA denotes Total TEU Allowance } \\
\text { Source: www.pancanal.com/peajes/ApprovedTollsTables.pdf }\end{array}$} & $\begin{array}{l}\text { Toll structure for full } \\
\text { container transiting } \\
\text { the Panama Canal (as } \\
\text { of April 1, 2016) }\end{array}$ \\
\hline
\end{tabular}

The expected impact of the opening of the expanded waterway on containership deployment patterns is large containerships of 5,300-10,000 TEUs, which has started to increasingly replace classic Panamax of 4,000 -5,100 TEUs. The rate of unemployment for larger vessels had fallen to extreme low, with further reactivations of vessels in this size have on the service particularly in peak seasons.

Many of these vessels are deployed on mainline trades from Asia to Europe and from Asia to North America as carriers tweak their capacity to meet demand, while some older sub-5,000 TEUs tonnage is forecast to be deployed on Asia-Middle East services; even former Panamax are flooding the market here. The surplus of classic Panamax is growing despite the fact that 22 units of 4,000-4,800 TEUs have already been sold for scrap in 2016.

On the other hand, as with 60 per cent of the cargo traffic transiting the canal beginning or ending its journey at a US port, competition between east and west coasts continues. However, so far, there is no dramatic shift from west coast to east coast of the USA following the new waterway expansion, but rather a new set of challenges in effectively handling the mega-vessels so that each coast can retain its market share.

From the point of view of global logistics, the Panama Canal is part of the integrated transport hub and will have a great impact on the Caribbean. The economic stability of the region largely depends on the safe and quick transport of 235 million tons more of cargo that is being transited through the canal annually.

The new expanded waterway of the Panama Canal, undoubtedly, will immensely enhance the value and advantage of Panama's blessed geographic location by making it the most important transshipment hub in the Americas from which it networks the global shipping.

\section{Conclusion and pending issues}

With the new expanded locks now set for their glorious opening in June 2016, the ACP and most carriers share much confidence about the future of the canal. It is expected that the 
MABR

2,3

\section{8}

expansion will result in greater demand for many of the goods and services provided by the cluster - the Panama Canal (Pagano et al., 2016). It is noteworthy that all the slots of container vessels were reserved for many days even at the maximum size much before the opening of the new waterway. Growth prospects are perceived as being highly promising.

However, on the other hand, the ACP has been paying attention on its neighboring rivalry - the alleged putative Nicaragua Canal, which will become a big threat to the Panama Canal when it opens. That being said, it is reckoned that even if it made a profit of $\$ 2$ bn a year, the Nicaragua Canal will take 25 years to pay off its debts, without giving any dividends to the investors. Under such strict and unpredictable circumstances, it is an extremely long way to go for the canal to be developed even though it is geographically near the Panama Canal.

Concerns have been raised regarding the maximum capacity of the new locks of the Panama Canal. In fact, the ACP has already conceived a plan to add the fourth set of locks in the future should more freight be needed to sail across the isthmus. With access channels already dredged, expanding another set of locks would be a relatively minor task as compared with what has been done for the construction of the third set of locks.

To sum up, the new waterway expansion of the Panama Canal is undoubtedly indispensable for being able to allow Post-Panamax and Neo-Panamax vessels carrying more freight to pass through when ocean carriers can substantially shorten the lead time and cut down logistics cost. At the same time, the ACP can enjoy the lucrative toll revenue annually.

The possibility of competitions coming far from the Suez Canal and near from the putative Nicaragua Canal might visit someday ahead. However, the pivotal status and the role of the Panama Canal in terms of international trade and global shipping simply cannot be ignored.

\section{Notes}

1. This is adopted from https://en.wikipedia.org/wiki/Hutchison_Whampoawithminorrevision

2. https://en.wikipedia.org/wiki/Panama_Canal_locks

3. As above.

4. Annual Report 2016, Canal De Panama.

5. This section is adopted from https://en.wikipedia.org/wiki/Panama_Canal\#Third_set_of_locks_project with minor revision.

6. This section is adopted from Ports \& Harbors (2009a) with minor revision.

7. The result shows that the enlarged ship size passing through the Panama Canal will increase the east coast players' market power by $32 \%$ while hurting the west coast players by $22 \%$. Refer to Liu et al. (2016) for more details.

8. Based on Ports \& Harbors (2016), with minor revision.

9. This section is adopted from https:/en.wikipedia.org/wiki/Panama_Canal\#Competition with minor revision.

10. https://en.wikipedia.org/wiki/Panama_Canal\#Tolls

11. Toll revenue contributed to an average of $5.39 \%$ of nominal GDP from 2008 to 2013 , though this figure has since declined to a low of just $4.37 \%$ during 2013. http://www.ceicdata.com/en/blog/ decline-panama-canal $\% \mathrm{E} 2 \% 80 \% 99$ s-toll-revenue 
12. https://en.wikipedia.org/wiki/Panama_Canal\#Tolls

\section{Role of \\ Panama Canal

13. https://en.wikipedia.org/wiki/Panama_Canal\#Tolls

14. For the expansion of the new waterway, the ACP does not have any loans from commercial banks but only multilateral agencies that invest in long-term projects. The remaining cash comes from canal-generated revenue. Refer Expanding horizons for Panama, Ports \& Harbors (2009b) for more details.

\section{References}

Annual Report (2014), Canal De Panama, p. 127

Liu, Q., Wilson, W.W. and Luo, M. (2016), "The impact of Panama canal expansion on the containershipping market: a cooperative game theory approach”, Maritime Policy \& Management, Vol. 43 No. 2, pp. 209-221.

Pagano, A., Wang, G., Sánchez, O., Ungo, R. and Tapiero, E. (2016), “The impact of the Panama canal expansion on Panama's maritime cluster", Maritime Policy \& Management, Vol. 43 No. 2, pp. 164-178.

Ports \& Harbors (2009a), “Dredging tomorrow's dimensions”, IAPH, Vol. 54, No. 3, pp. 24-25.

Ports \& Harbors (2009b), "Dredging tomorrow's dimensions", IAPH, Vol. 54 No. 3, pp. 30-31.

Ports \& Harbors (2016), "Steady as she flows", IAPH, Vol. 61 No. 6, p. 20.

Sampson, R.D., Farris, M.T., and Shrock, D.L. (1990), Domestic Transportation: Practice, Theory, and Policy, 6th ed., Hougton Mifflin Company, Boston, Chapter 2.

Wood, D.F., Barone, A., Murphy, P., and Wardlow, D. (1995), International Logistics, Chapman \& Hall, New York, NY, p. 201.

\section{Further reading}

Annual Report (1999/2014), Canal De Panama.

Baker, J. (2016a), "Panama unlock gates to new trade lanes”, Containerisation International, pp. 41-42.

Baker, J. (2016b), “The panama papers”, Containerisation International, pp. 10-11.

Conway, M. (2007), “Keep on moving”, Ports \& Harbors, IAPH, Vol. 52 No. 1, pp. 16-17.

Ducruet, C. (2016), "The polarization of global container flows by interoceanic canals: geographic coverage and network vulnerability", Maritime Policy \& Management, Vol. 43 No. 2, pp. 242-260.

Fox News (2012), "Houston's high expectations for panama canal expansion”, 21 February.

Knowler, G. (2016), "Direct port calls hurt Asia's transshipment hubs", Ports \& Harbors, IAPH, Vol. 61 No. 4, p. 32.

Laulajainen, R., Holgerson, T., Stromberg, A.B. (2001), "Operating Panamax dry bulk carriers on the seven seas", Gothenburg School of Economic and Commercial Law.

Nightingale, L. (2016a), "Panama canal sets June 26 opening date for new locks", Containerisation International, April, p. 54.

Nightingale, L. (2016b), "Small is beautiful”, Containerisation International, April, pp. 20-21.

Slinn, T. (2006), "Post-Panamax? I hate that term”, Ports \& Harbors, IAPH, Vol. 51 No. 3, pp. 26-31.

Slinn, T. (2009), "Dredging tomorrow's dimensions", Ports \& Harbors, IAPH, Vol. 54 No. 3, pp. 24-25.

Wang, M. (2014), Global Logistics and Shipping Alliance, Tendodo Books, Beppu. 
MABR

2,3

260

\section{Websites}

http://cnx.org/contents/b8228711-92db-4aeb-b44c-729c6bf70454@7/A-Global-View-of-Disease-Yello http://kristensosulski.blogspot.jp/2011/10/visualizations-of-panama-canal

www.worldatlas.com/aatlas/infopage/capehorn.htm

https://en.wikipedia.org/wiki/CK_Hutchison_Holdings

https:/en.wikipedia.org/wiki/Panama_Canal_locks

https:/en.wikipedia.org/wiki/Culebra_Cut

http://maritime-connector.com/wiki/panamax/

https://en.wikipedia.org/wiki/Tonnage

www.ceicdata.com/en/blog/decline-panama-canal $\%$ E2\%80\%99s-toll-revenue

https://en.wikipedia.org/wiki/Panama_Canal\#Competition

https:/en.wikipedia.org/wiki/Panama_Canal\#Tolls

https://en.wikipedia.org/wiki/Panama_Canal\#Third_set_of_locks_projec

www.lexology.com/library/detail.aspx?g=10ad6d13-b0d0-4f1d-a071-c9381c57e9b4

\section{Corresponding author}

Mariner Wang can be contacted at: sot07762@apu.ac.jp

For instructions on how to order reprints of this article, please visit our website: 